\title{
Re-emergence of O103: H2 Shiga toxin-producing Escherichia coli infections in São Paulo, Brazil
}

\begin{abstract}
Shiga toxin-producing Escherichia coli (STEC) is an important cause of gastroenteritis in developed countries, and symptoms include mild to severe diarrhoea and haemorrhagic colitis (HC) that may be complicated with haemolytic uraemic syndrome (HUS). STEC O157: H7 is a prominent pathogen worldwide, but the occurrence of non-O157 STEC infections is increasing in several regions, and particular non-O157 serogroups associated with pathogenicity include $\mathrm{O} 26, \mathrm{O} 91, \mathrm{O} 103$ and O111 (Paton \& Paton, 1998).
\end{abstract}

In Brazil, infections due to STEC have been mainly reported as associated with sporadic cases of non-bloody diarrhoea, particularly in young children (Giraldi et al., 1990; Cantarelli et al., 2000; Guth et al., 2000). Despite the lack of a nationwide surveillance system for HC and HUS, isolation of O157 : H7 strains from bloody diarrhoea (Irino et al., 2002) and of O26: H11 from one HUS case (Guth et al., 2002) have been recently described in Brazil. Moreover, nonO157 STEC have been circulating as agents of infantile diarrhoea in São Paulo State since the late 1970s, with serotypes O111: NM, O111:H8 and O26:H11 accounting for most of the cases (Vaz et al., 2004), indicating the occurrence of important enterohaemorrhagic E. coli (EHEC) strains in our settings, which is certainly a public health concern.

It is known that the predominance of nonO157 STEC strains may vary depending on the region analysed, and O103: H2 STEC strains have been reported as an important cause of gastroenteritis and HUS in several European countries (Eklund et al., 2001; Prager et al., 2002) and in the USA (Tarr et al., 1996). To our knowledge the only mention of an infection by O103: H2 STEC in Brazil dates from 1986, when it was isolated from a 3-month-old child with non-bloody diarrhoea (Guth et al., 2000). In this report the re-emergence of $\mathrm{O} 103: \mathrm{H} 2$ STEC strains as recent causes of infantile diarrhoea and haemolytic anaemia in São Paulo State is addressed.
Three cases of O103: H2 STEC infection were identified in Brazil during the period 2000-2002. One of the strains was isolated from the stools of a 24-month-old child with haemolytic anaemia and the two others were isolated from faecal specimens of 18and 24-month-old children with nonbloody diarrhoea. E. coli strains were isolated from the stools of these patients by standard procedures, identified as STEC by detection of Shiga toxin $(s t x)$, intimin (eae) and enterohaemolysin $(e h x)$ gene sequences, and serotyped as previously described (Vaz et al., 2004). All the strains carried st $x_{1}$, eae and $e h x$, and one of them harboured additionally the stx $x_{2}$ and $s t x_{2}$ vha sequences, which were determined by RFLP-PCR (Guth et al., 2003). Intimin type $\varepsilon$ was identified in all of them (Oswald et al., 2000). The stx 1 eae ehx virulence profile is commonly observed among strains of this serotype isolated in other regions (Eklund et al., 2001; Prager et al., 2002; Tarr et al., 1996), and was also harboured by the STEC strain isolated in São Paulo in 1986 (Table 1).

Cattle represent the main reservoir of STEC, and thus most of the outbreaks and sporadic cases of human infections have been associated with the consumption of contaminated food, the major vehicles of infection being undercooked ground beef and unpasteurized milk. As non-O157 STEC strains are more prevalent in animals and as contaminants of foods than O157 STEC strains, humans are probably more exposed to these organisms. The occurrence of O103 : H2 STEC strains in cattle had been described in some studies (Zweifel et al., 2005). However, in Brazil these strains have not been isolated from animals or foods (Cerqueira et al., 1997; Irino et al., 2005), making any analysis of probable infection sources difficult.

The real incidence of $\mathrm{O} 157$ and nonO157: H7 STEC infections in Brazil is not easy to establish since only a few laboratories adhered to diagnostic methods for $\mathrm{O} 157$ identification and the search for non-O157 STEC strains is only performed in some reference laboratories. Nevertheless, O103: H2 STEC has re-emerged in São Paulo State as a cause of disease, and although still in low numbers the search for this particular EHEC serotype should be implemented. The molecular analysis of human STEC strains isolated in Brazil, including those of serogroup O103, is being undertaken in our laboratory.

\section{Acknowledgements}

This work was supported by grants from Fundação de Amparo à Pesquisa do Estado de São Paulo (FAPESP) and Conselho Nacional de Desenvolvimento Científico e Tecnológico, CNPq, Brazil.

Beatriz E. C. Guth, ${ }^{1}$ Tânia M. I. Vaz,, ${ }^{1,2}$ Tânia A. T. Gomes, ${ }^{1}$ Silvia H. Chinarelli, ${ }^{3}$ Marilu M. M. Rocha, ${ }^{4}$

Antônio Fernando Pestana de Castro ${ }^{5}$ and Kinue Irino ${ }^{2}$

${ }^{1}$ Departamento de Microbiologia,

Table 1. Characteristics of $\mathrm{O} 103$ : H2 STEC strains isolated in São Paulo, Brazil

\begin{tabular}{|c|c|c|c|c|}
\hline Strain & $\begin{array}{c}\text { Date of isolation } \\
(\mathrm{mm} / \mathrm{yy})\end{array}$ & $\begin{array}{l}\text { Age of patient } \\
\text { (months) }\end{array}$ & $\begin{array}{l}\text { Patient's } \\
\text { condition* }\end{array}$ & Virulence markers \\
\hline 651-1 & $07 / 86$ & 3 & D & stx $x_{1}$ eae ehx \\
\hline $495 / 12$ & $12 / 00$ & 18 & $\mathrm{D}$ & stx $x_{1}$ eae ehx \\
\hline $437 / 01$ & $10 / 01$ & 24 & HA & stx $x_{1}$ eae ehx \\
\hline 91 & $09 / 02$ & 24 & $\mathrm{D}$ & $s t x_{1}$ stx $x_{2} s t x_{2 \text { vha }}$ eae ehx \\
\hline
\end{tabular}

${ }^{\star} \mathrm{D}$, diarrhoea; HA, haemolytic anaemia. 
Imunologia e Parasitologia, Universidade Federal de São Paulo - Escola Paulista de Medicina, São Paulo, Brazil

${ }^{2}$ Instituto Adolfo Lutz, São Paulo, Brazil

${ }^{3}$ Instituto Adolfo Lutz, Ribeirão Preto, São Paulo, Brazil

${ }^{4}$ Instituto Adolfo Lutz, Campinas, São Paulo, Brazil

${ }^{5}$ Departamento de Microbiologia, Instituto de Ciências Biomédicas II, Universidade de São Paulo, São Paulo, Brazil

Correspondence: Beatriz E. C. Guth (becguth@ecb.epm.br)

Cantarelli, V., Nagayama, K., Takahashi, A., Honda, T., Cauduro, P. F., Dias, C. A. G., Mezzari, A. \& Brodt, T. (2000). Isolation of Shiga toxin-producing Escherichia coli (STEC) serotype O91: H21 from a child with diarrhea in Porto Alegre city, RS, Brazil. Braz J Microbiol 31, 266-270.

Cerqueira, A. M. F., Tibana, A. \& Guth, B. E. C. (1997). High occurrence of Shiga-like-toxinproducing strains among diarrheagenic Escherichia coli isolated from raw beef products in Rio de Janeiro City, Brazil. J Food Protect 60, 1-5.

Eklund, M., Scheutz, F. \& Siitonen, A. (2001). Clinical isolates of non-O157 Shiga toxinproducing Escherichia coli: serotypes, virulence characteristics, and molecular profiles of strains of the same serotype. J Clin Microbiol 39, 2829-2834.

Giraldi, R., Guth, B. E. C. \& Trabulsi, L. R. (1990). Production of Shiga-like toxin among
Escherichia coli strains and other bacteria isolated from diarrhea in São Paulo, Brazil. $J$ Clin Microbiol 28, 1460-1462.

Guth, B. E. C., Ramos, S. R. T. S., Cerqueira, A. M. F., Andrade, J. R. C. \& Gomes, T. A. T. (2000). Characterization of Shiga toxinproducing Escherichia coli (STEC) strains isolated from children in São Paulo, Brazil. In Abstracts of the 4th International Symposium and Workshop on Shiga Toxin (Verocytotoxin)Producing Escherichia coli Infections, Kyoto, Japan, p. 149.

Guth, B. E. C., Lopes, R., Vaz, T. M. I. \& Irino, K. (2002). First Shiga toxin-producing Escherichia coli isolate from a patient with hemolytic uremic syndrome in Brazil. Emerg Infect Dis 8, 535-536.

Guth, B. E. C., Chinen, I., Miliwebsky, E., Cerqueira, A. M. F., Chillemi, G., Andrade, J. R. C., Baschkier, A. \& Rivas, M. (2003). Serotypes and Shiga toxin genotypes among Escherichia coli strains isolated from animals and foods in Argentina and Brazil. Vet Microbiol 92, 335-349.

Irino, K., Vaz, T. M. I., Kato, M. A. M. F. \& 7 other authors (2002). O157: H7 Shiga toxinproducing Escherichia coli strains associated with sporadic cases of diarrhea in São Paulo, Brazil. Emerg Infect Dis 8, 446-447.

Irino, K., Kato, M. A. M. F., Vaz, T. M. I., Ramos, I. I., Souza, M. A. C., Cruz, A. S., Gomes, T. A. T. Vieira, M. A. M. \& Guth, B. E. C. (2005).

Serotypes and virulence markers of Shiga Toxin-Producing Escherichia coli (STEC) isolated from dairy cattle in São Paulo State, Brazil. Vet Microbiol 105, 29-36.
Oswald, E., Schmidt, H., Morabito, S., Karch, H., Marches, O. \& Caprioli, A. (2000). Typing of intimin genes in human and animal enterohemorrhagic and enteropathogenic Escherichia coli: characterization of a new intimin variant. Infect Immun 68, 64-71.

Paton, J. C. \& Paton, A. W. (1998).

Pathogenesis and diagnosis of Shiga toxinproducing Escherichia coli infections. Clin Microbiol Rev 11, 450-470.

Prager, R., Liesegang, A., Voigt, W., Rabsch, W., Fruth, A. \& Tschäpe, H. (2002). Clonal diversity of Shiga toxin-producing Escherichia coli $\mathrm{O} 103: \mathrm{H} 2 / \mathrm{H}^{-}$in Germany. Infect Genet Evol 1, 265-275.

Tarr, P. I., Fouser, L. S., Stapleton, A. E., Wilson, R. A., Kim, H. H., Vary, J. C. \& Clausen, C. R. (1996). Hemolytic-uremic syndrome in a 6-year-old girl after an urinary tract infection with Shiga-toxin-producing E. coli $\mathrm{O} 103$ : $\mathrm{H} 2$. $N$ Engl J Med 335, 635-638.

Vaz, T. M. I., Irino, K., Kato, M. A. M. F., Dias, Â. M. G., Gomes, T. A. T., Medeiros, M. I. C., Rocha, M. M. M. \& Guth, B. E. C. (2004).

Virulence properties and characteristics of Shiga toxin-producing Escherichia coli in São Paulo, Brazil, from 1976 through 1999. J Clin Microbiol 42, 903-905.

Zweifel, C., Schumacher, S., Blanco, M., Blanco, J. E., Tasara, T., Blanco, J. \& Stephan, R. (2005). Phenotypic and genotypic characteristics of non-O157 Shiga toxinproducing Escherichia coli (STEC) from Swiss cattle. Vet Microbiol 105, 37-45. 